\title{
Thoughts of Health Workers Related to the Organizational Changes of Turkish Health System
}

\author{
Nuriye Çelmeçe ${ }^{1}$ \\ South Russian University
}

\author{
Yasemin Ayyldiz ${ }^{2}$ \\ South Russian University
}

\author{
Abdullah Işıklar ${ }^{3}$ \\ Bursa Technical University
}

\begin{abstract}
The target of this study is to examine how the organizational changes of Turkish Health System are perceived by nurses, laboratory assistants, radiology experts and secretaries according to their seniorities. This study is investigated by means of a Relational Screening Model. In this research, an Accidental Sampling Model is used. The study reached 170 healthcare workers from different jobs who worked in the Central State Hospital in Tokat City and in total 150 people were included in 2014. The data of the research was counted via a two parted questionnaire. The first questionnaire is composed of gender, occupational satisfaction and occupational type. And the second one consists of Multi-Likert Testimony which is formed with questions (Totally Agree-Agree-Undecided-Disagree-Extremely Disagree) about the healthcare organizational changes. According to the results of the research, there is not a meaningful difference between the healthcare workers' gender and their thoughts about organizational changes. There is not a meaningful difference between the health workers' occupational satisfaction and their thoughts about the healthcare organizational changes. On the other hand, it is found that there is a meaningful difference between the health workers' seniority and their thoughts about the healthcare organizational changes and the specification and planning. And there is a meaningful difference between the healthcare workers' occupational types and organizational change need, planning, practicing, evaluating and philosophy of nurses. It can be said that in general, there is a positive approach towards the change. According to the findings of this study, there is a meaningful difference between planning and the needs of senior healthcare workers when all sub-findings of nurses' perceptions about the organizational change of healthcare workers are examined.
\end{abstract}

Keywords

Change • Organization $\bullet$ Health System • Organizational Change $\bullet$ Change in the health system

\footnotetext{
1 Correspondence to: Nuriye Celmeçe, Institute of Management, Business and Law, Management in Healthcare, South Russian University, Rostov-Na-Donu, Russian Federation. Email: nuriye_celmece@hotmail.com

2 Institute of Management, Business and Law, Industrial and Organizational Psychology, Russian Federation. Email: oflu_kimyager@hotmail.com

3 Faculty of Humanities and Social Sciences, Bursa Technical University, Bursa Turkey. Email: psikoapo@hotmail.com
}

Citation: Çelmeçe, N., Ayyıldız, Y., \& Işılklar, A. (2016). Thoughts of health workers related to the organizational changes of turkish health system. Sanitas Magisterium, 2, 41-52. http://dx.doi.org/10.12738/SM.2016.1.0017 
Each country has social systems which are responsible for sustaining life-order in coordination with economic, social, technological and scientific changes.

Change in social system effect qualifications of individuals' roles in those social systems, their thoughts, and their views about social-political and cultural events, producing styles related to producing and possession relationships, technological levels they have reached, and laws they had to obey that force a change (Özy1lmaz, 2013).

Innovation strategies of organizations can include fulfilling the expectations of customers and organizational norms, environmental features, leadership in the organization, and communication in and out of the organization (Kabakçı, 2008).

In the world today, with the idea of new public operations, there occurs changes in personnel improvement and evaluation, and the employment system of the government in parallel to the change in organizing and in processing style of the government (Batchelder \& Alexander, 2009).

To see these changes and evaluate them with the changes in government is highly important in the field of observing the whole picture of the public personnel system.

One of the areas which we can evaluate the practice by means of changes in the public personnel system in Turkey is the healthcare sector. Healthcare is one of the first sectors in which practices about personnel administration are implemented by new public management.

For example, the Ministry of Health is the first ministry in which performance evaluation and supplementary payment systems were practiced. In addition, after the Ministry of Education, the Ministry of Health is where the most public personnel are employed. In this sense, changes in employment in the Ministry of Health have an effect on employment in Turkey (Sayan \& Küçük, 2012).

Change effects the expectations of people about security and stability. Especially change without planning and broad participation, which leads people to feelings of insecurity and danger (Yousef, 2000). For this reason, it is inevitable that organizations will change into troublesome, anxious and furious groups if the staff has not participated in the decision of the change and been persuaded about the danger which is expected, even when the organizational changes have are meant to spark excitement and innovation (Doyle, 1995).

This research is focused on the question: "How does an occupational organization react to a public change brought about by the government?" In this study, it is being checked weather there is an effect of the norms of occupational organizations on is forming in organizational field (DiMaggio \& Powel, 1991). 
Accordingly, this study examines the health workers' change, how the change administration is perceived and, views about the change.

\section{Forming Health Policies and Organizational Change in Healthcare Institutions}

The change in health services is related to structures (integrated service networks or integrated pathology practices) and processes (healthcare points and unattempting tests) (Hernandez, 2010).

The change takes shape in these courses, and healthcare workers, patients (customers), and other factors have an effective role in success from the change. From this point on, there is a need to act along with all participants of the organization while performing any change.

Forming the health policy, when the individual's health, the health system of the country, and main factors effecting the process are totally examined, the legal health policy in a country is the very first determiner of indicators of that country. The importance of individuals' attention to their own health, is the second determiner which indicates the effectiveness of the health system and health policies. The economic situation and the distribution of income are the third indicator (Sargutan, 2005).

In order to keep up with current times, continuously, there have been revisions and regulations in the fields of social and cultural changes. Modifying and adapting by means of modernization changes and attempts at reform in health services are seen as a must on the winds of change.

Increases in the expenses for health services, citizens' high expectations, and trouble in the payment capacity of the countries make it difficult to renew the health services. Since 2003, there have been studies about reforms in healthcare changing programs. As a result of these studies, some public institutions were reassigned to the Ministry of Health. Then, transition towards supplementary payments for measurable performance improvements have come into existence. Government workers and members of the Retirement Fund could now use private health institutions. Family physician implementations, along with many attempts at Green Card policies and medicine purchasing protocols started (Gümüssel, 2006).

The target of this study is to examine:" How are the changes in healthcare organization perceived by healthcare staff according to some variances?"

\section{Problem Sentence}

Do healthcare workers, nurses, laboratory assistants, radiology experts, and secretaries' attitudes towards the Organizational Healthcare System Change differ according to some variances?

Finding the answer to this question was tried via these sub-problems. 


\section{Sub-Problems}

1. According to the gender, do healthcare workers' thoughts about the Healthcare Organizational Change differ in terms of specifying the need, planning, practice, evaluation, and philosophy?

2. According to their occupational satisfaction, do healthcare workers' thoughts about the Healthcare Organizational Change differ in terms of specifying the need, planning, practice, evaluation, and philosophy?

3. According to occupational seniority, do healthcare workers' thoughts about the Healthcare Organizational Change differ in terms of specifying the need, planning, practice, evaluation, and philosophy?

4. According to the occupational type variance, do healthcare workers' thoughts about the Healthcare Organizational Change differ in terms of specifying the need, planning, practice, evaluation and philosophy?

\section{Method}

In this study, a Relational Screening Model based upon a General Screening Model is used. The Screening Model is a technique which aims to depict a situation that existed once or is still. In the General Screening Model, in many existing populations, in order to reach a conclusion, either the whole population or a subgroup or subgroups are taken from the population to be scanned (Karasar, 2002).

\section{Population and Sample}

The population of the study includes the doctors, nurses, healthcare officers, laboratory assistances, radiology experts, and secretaries working at the Central State Hospital of the Ministry of Health, in Tokat City. And in the sample, 75 nurses, 27 laboratory assistances, 18 radiology experts, and 30 secretaries (totaling 150 workers86 female and 64 male) were chosen via the Cluster Sampling Method.

\section{Collecting the Data}

Organizational Parameter Measurement. Organizational Parameter Measurement is formed of two parts. In the first part, there are questions about gender, occupational seniority etc. In the second part, there are questions on the thoughts of the healthcare workers towards the organizational change. The healthcare workers were asked to choose one of these: Totally Agree- Agree-Undecided- DisagreeExtremely Disagree. "Formula n-1/n" was used to find the level of "Agree." 
After the counting, the proportion of 1-5 was 0.8 . To ensure the validity of the scale, the Content Validity Scale was used. Content Validity is determined by the expert who determines if the questions are suitable for measurement and represent the desired field (Karasar, 2009). Necessary changes to the scale questions were done with expert views.

The scale reliability was checked in two steps by its creators, Tanriöğen and Kurşunoğlu: Pilot Study and True Practice. According to the results taken from the true practice period, the Reliability Coefficient of the Whole Questionnaire is Alpha Cronbach .94.

Data analysis. SPSS (Statistical Package for Social Sciences) was used for Data Analysis. To find answers to sub-problems Standard Deviation, the $t$-Test, ANOVA Test etc. were used. Significance level .5 was found after these statistical analysis.

\section{Findings}

1. Do the healthcare workers' thoughts about the Healthcare Organizational Changes differ according to the gender?

\begin{tabular}{lccccc}
\hline Table 1 & \multicolumn{6}{c}{} \\
Independent Samples & T-Test Results & Used to Find out if the Healthcare Organizational Changes Show a \\
Diversity according to the gender Variance & & & & \\
\hline Gender & $\mathrm{N}$ & $\bar{X}$ & $\mathrm{Sd}$ & $t$ & $p$ \\
Female & 86 & 230.3140 & 148 & 1.081 & .281 \\
Male & 64 & 226.2969 & & & \\
\hline
\end{tabular}

When Table 1 is examined, it is observed that the views of female healthcare workers about the Healthcare Organizational Changes do not meaningfully differ according to the gender variance $(p=.281>.05)$.

2. Do the healthcare workers' thoughts about the Healthcare Organizational Changes differ according to their occupational satisfaction?

Table 2

Independent Samples t-Test Results Used to Find out if the Healthcare Organizational Changes Show a Diversity according to the Occupational Satisfaction Variance

\begin{tabular}{lccccc}
\hline Satisfaction & $\mathrm{N}$ & $\bar{X}$ & $\mathrm{Sd}$ & $t$ & $p$ \\
Yes & 81 & 226.1358 & 148 & -1.458 & .147 \\
No & 69 & 231.4928 & & & \\
\hline
\end{tabular}

When Table 1 is examined, it is observed that the views of healthcare workers about the Healthcare Organizational Changes do not meaningfully differ according to their occupational satisfaction variance $(p=.147>.05)$.

3. Do the healthcare workers' thoughts about the Healthcare Organizational Changes differ according to their occupational seniority? 
Table 3.1

One-way Analysis of Variance Results Used to Find Out if the Healthcare Organizational Changes Show a Diversity According to the Occupational Seniority Variance

\begin{tabular}{llcccc}
\hline Experience Group & $N$ & $\bar{X}$ & sd & $F$ & $p$ \\
$0-5$ years & 54 & 227.1296 & & & $.024^{*}$ \\
6-10 years & 50 & 223.6000 & 2 & 3.183 & \\
11-15 years & 46 & 235.7609 & & & \\
\hline
\end{tabular}

On the basis of this hypothesis, the results of One-Way Analysis of Variance are given in Table 3.1. According to the results of this analysis $(p=.024>.05)$, at least one of the averages of the experienced workers of $0-5,6-10,11-15$ years show a difference compared to the others.

\begin{tabular}{lllcc}
\hline $\begin{array}{l}\text { Table } 3.2 \\
\text { One way Analysis of Variance Results }\end{array}$ Used to Find out if the Sub-dimension Points Show a Diversity \\
according to Occupational Seniority Variance
\end{tabular}

On the basis of this hypothesis, the results of One-Way Analysis of Variance are given in Table 3.2. According to the analysis, it is found that in the need for organizational change $(p=.48<.05)$ at least one of the averages of the experienced workers of $0-5,6-10$, and 11-15 years and organizational change planning show a difference from the others.

When Table 3.3 is examined, in the field of "Organizational change needs" it is found that there occurs a difference between the 0-5 years experienced healthcare workers' thoughts about organizational change and that of the 11-15 years experienced workers' thoughts. According to the statistical analysis, in the sub-dimension of specification in "Organizational change needs", there is a meaningful difference between occupational seniority of the 0-5 years experienced groups and the 11-15 years experienced groups $(p=.037)$. 
Table 3.3

Tukey HSD Comparison Results Showing the Meaningful Difference Source of the Sub-dimension Points of Organizational Change according to the Occupational Seniority Variance

\begin{tabular}{|c|c|c|c|c|c|}
\hline Org. Change & I & $\mathrm{J}$ & Mean Dif.(I-J) & SHx & $p$ \\
\hline \multirow{3}{*}{ Sample Specification } & $0-5$ years & 6-10 years & -1.0577 & 0.94591 & .504 \\
\hline & & 11-15 years & -2.4082 & 0.96702 & .037 \\
\hline & $6-10$ years & $11-15$ years & -1.3504 & 0.98466 & .359 \\
\hline \multirow{3}{*}{ Planning } & $0-5$ years & 6-10 years & 2.7814 & 1.8673 & .299 \\
\hline & & $11-15$ years & -3.2141 & 1.9438 & .215 \\
\hline & $6-10$ years & $11-15$ years & -5.9956 & 1.9438 & .007 \\
\hline
\end{tabular}

When Table 3.3 is examined, in the field of "Organizational change needs" it is found that there occurs a difference between the 6-10 years experienced group healthcare workers' thoughts about organizational change and that of the 11-15 years experienced workers' thoughts. According to the statistical analysis, in the sub-dimension of specification for organizational change needs, there is meaningful difference between occupational seniority of the 6-10 years experienced group and the 11-15 years experienced group $(p=.007)$.

4. Do the healthcare workers' thoughts about the Healthcare Organizational Changes differ according to their occupational type?

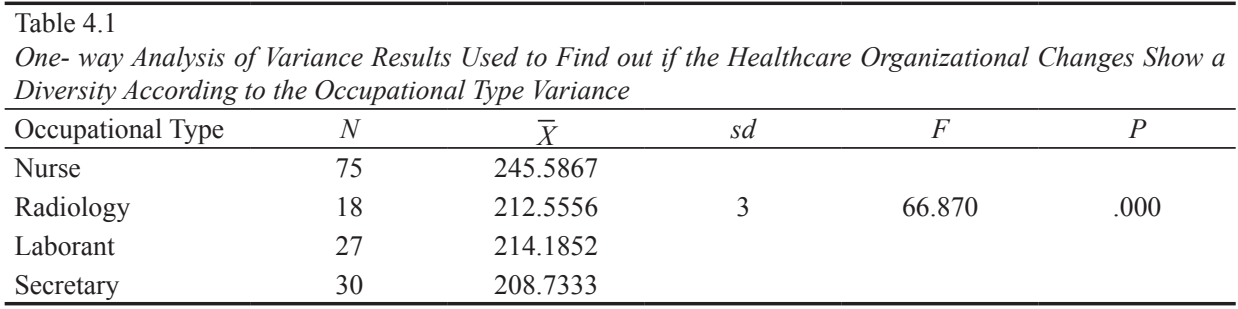

On the basis of this hypothesis, the results of One-Way Analysis of Variance are given in Table 4.1. According to the analysis, it is observed that at least one of the averages differs from the others $(F=66.870 p=.000<.05)$.

According to this hypothesis, the results of One-Way Analysis of Variance are given in Table 4.2. At the end of the analysis, it is found that at least one of the averages differs from the others. 


\begin{tabular}{|c|c|c|c|c|}
\hline $\begin{array}{l}\text { Table } 4.2 \\
\text { One-way Analysis of Varia } \\
\text { According to the Occupation }\end{array}$ & $\begin{array}{l}s \text { Us } \\
\text { rianc }\end{array}$ & out if the & ension $P$ & $a D$ \\
\hline Organizational Change & $N$ & $\bar{X}$ & $F$ & $p$ \\
\hline Sample Specification Nurse & 75 & 36,4933 & & \\
\hline Radiology & 18 & 32.8333 & 6.609 & .000 \\
\hline Laborant & 27 & 33.2222 & & \\
\hline Secretary & 30 & 33.2333 & & \\
\hline Planning Nurse & 75 & 83,7867 & & \\
\hline Radiology & 18 & 70.2778 & 61.413 & .000 \\
\hline Laborant & 27 & 69.3704 & & \\
\hline Secretary & 30 & 68.6333 & & \\
\hline Practice Nurse & 75 & 38,2133 & & \\
\hline Radiology & 18 & 34.2778 & 14.022 & .000 \\
\hline Laborant & 27 & 35.2222 & & \\
\hline Secretary & 30 & 32.9000 & & \\
\hline Evaluation Nurse & 75 & 33,1600 & & \\
\hline Radiology & 18 & 28.1111 & 39.814 & .000 \\
\hline Laborant & 27 & 28.0741 & & \\
\hline Secretary & 30 & 27.5333 & & \\
\hline Philosophy Nurse & 75 & 53,5200 & & \\
\hline Radiology & 18 & 46.7222 & 23.266 & .000 \\
\hline Laborant & 27 & 48.0370 & & \\
\hline Secretary & 30 & 46.3000 & & \\
\hline
\end{tabular}

Table 4.3

Tukey HSD Comparison Results Showing the Meaningful Difference Source of the Sub-dimension Points of Organizational Change According the Occupational Type Variance

\begin{tabular}{|c|c|c|c|c|c|}
\hline Organizational Change & (I) Occup. & (J)Occup. & Mean Diff.(I-J) & SHx & $p$ \\
\hline \multirow[t]{6}{*}{ Sample Specification } & \multirow[t]{3}{*}{ Nurse } & Radiology & $3.6600^{*}$ & 1.2159 & .016 \\
\hline & & Laborant & $3.2711^{*}$ & 1.0397 & .011 \\
\hline & & Secretary & $3.2600^{*}$ & 1.0007 & .008 \\
\hline & \multirow[t]{2}{*}{ Radiology } & Laborant & -0.38889 & 1.4096 & .993 \\
\hline & & Secretary & -0.40000 & 1.3811 & .992 \\
\hline & Laborant & Secretary & -0.01111 & 1.2289 & 1.00 \\
\hline \multirow[t]{6}{*}{ Planning } & \multirow[t]{3}{*}{ Nurse } & Radiology & $13.508^{*}$ & 1.7188 & .000 \\
\hline & & Laborant & $14.416^{*}$ & 1.4697 & .000 \\
\hline & & Secretary & $15.153^{*}$ & 1.4147 & .000 \\
\hline & \multirow[t]{2}{*}{ Radiology } & Laborant & 0.90741 & 1.9927 & .968 \\
\hline & & Secretary & 1.6444 & 1.9524 & .834 \\
\hline & Laborant & Secretary & 0.73704 & 1.7372 & .974 \\
\hline \multirow[t]{6}{*}{ Practice } & \multirow[t]{3}{*}{ Nurse } & Radiology & $3.9355^{*}$ & 1.0877 & .002 \\
\hline & & Laborant & $2.9911^{*}$ & 0.93012 & .009 \\
\hline & & Secretary & $5.3133^{*}$ & 0.89527 & .000 \\
\hline & \multirow[t]{2}{*}{ Radiology } & Laborant & -0.9444 & 1.2610 & .877 \\
\hline & & Secretary & 1.3777 & 1.2355 & .681 \\
\hline & Laborant & Secretary & 2.3222 & 1.0993 & .154 \\
\hline \multirow[t]{6}{*}{ Evaluation } & \multirow[t]{3}{*}{ Nurse } & Radiology & $5.0488^{*}$ & 0.78053 & .000 \\
\hline & & Laborant & $5.0859^{*}$ & 0.66743 & .000 \\
\hline & & Secretary & $5.6266^{*}$ & 0.64242 & .000 \\
\hline & \multirow{2}{*}{ Radiology } & Laborant & 0.03704 & 0.90491 & 1.00 \\
\hline & & Secretary & 0.57778 & 0.88663 & .915 \\
\hline & Laborant & Secretary & 0.54074 & 0.78888 & .903 \\
\hline \multirow{6}{*}{ Philosophy } & \multirow[t]{3}{*}{ Nurse } & Radiology & $6.7977^{*}$ & 1.2668 & .000 \\
\hline & & Laborant & $5.4829^{*}$ & 1.0833 & .000 \\
\hline & & Secretary & $7.2200^{*}$ & 1.0427 & .000 \\
\hline & \multirow{2}{*}{ Radiology } & Laborant & -1.3148 & 1.4687 & .807 \\
\hline & & Secretary & 0.42222 & 1.4390 & .991 \\
\hline & Laborant & Secretary & 1.7370 & 1.2804 & .529 \\
\hline
\end{tabular}


When Table 4.3 is examined, the organizational change in all sub-dimensional variances of occupational type is seen between nurses and radiology experts, laboratory assistants, and secretaries. According to statistical analysis, there is a meaningful difference between nurses and other occupational types in the fields of specification of organizational change need, planning, practice, evaluation, and philosophy $(p=.000)$.

\section{Discussion}

In this study, in which hospital workers' attitudes towards Organizational Change is examined, findings about the research results were questioned according to literature and studies on Organizational Change and were evaluated by means of analysis.

In the first sub-question of the research, according to healthcare workers' gender, dimensions in philosophy, evaluation, practice, planning, and specification of organizational change needs were examined and no meaningful difference among the findings of the research was reached. In his study Gül, found there is no difference between females and males, when attitude is examined according to the gender, leadership, process, and resistance to the change process (Gül, 2014). Uslu, with his study, believes that according to the gender, both groups in hospital, have the necessary background and knowledge (Uslu, 2006). These two findings support study.

In the second sub-problem, according to the healthcare workers' occupational satisfaction, dimensions in philosophy, evaluation, practice, planning, and specifying of organizational change needs were examined and no meaningful difference between the findings of the research and occupational satisfaction was found.

In the third sub-problem of the research, according to the healthcare workers' occupational seniority, the dimensions in philosophy, evaluation, practice, planning, and specifying of organizational change needs was examined and a meaningful difference between the healthcare workers' seniority and on the basis of Organizational Change Need and planning levels was found. And it was observed that there was an elevation among the 11-15 years experienced healthcare workers. Gül couldn't find a statistically meaningful difference between the leadership and the resistance management in the change according to seniority of the workers (Gül, 2014). This study does not support ours in the field of the leadership in Organizational Change Need and planning.

In the last sub-problem of the research, according to the healthcare workers' occupational types, the dimensions in philosophy, evaluation, planning, practice, and specifying the organizational change needs of the healthcare system were examined. According to the healthcare workers' occupational types, their thoughts on organizational change in all dimensions, a meaningful difference for nurses was found. In his study on nurses' thoughts about directing the change, Dağ found $68 \%$ of nurses had thought the reason for the change 
was caused by legal obligations (Dağ, 2010). Although this study has a partial parallel with our research, nurses, in all sub-variances: philosophy, evaluation, practice, planning, and specifying the organizational change need, show a meaningful difference.

It can be said that in our questionnaire study, there was a positive approach towards the change. In the modern world order, change is accepted. At this point, it is important to confirm the needs, and this is supported by the findings, which show a meaningful difference, especially between specifying the 11-15 years experienced workers' needs and planning. In the results of occupational type variance, it is pointed out that nurses are more sensitive than the other healthcare workers.

It is highly focused in many resources that in countries where healthcare reform programs are implemented, healthcare services should be offered under free market conditions (Guevera \& Mendida, 2002; Homedes \& Ugalde, 2005). Seren, in his "Transformation in Healthcare Project" study, reached that the highly accepted statements that "Hospitals should be transformed into business firms," and "Patients are seen as customers." Via our questionnaire, a meaningful difference between specifying the organizational change needs of more experienced workers and planning was reached. And in all levels of organizational change, there is a meaningful difference among the nurses' thoughts on the change. This is very important both for supporting our study and to have a more general result.

As a conclusion, the change is an un-ignorable truth of our age. Healthcare Institutions should be up to date for the accelerating changes and should be qualified to harmonize to these changes. It is inevitable that organizational changes will take the institutions in to the future. But in this period, many problems can be faced. Each organization has to act according to the problems traced in this change period as well as thinking of the benefits of the change. Because the change is not a simple time period. There will of course be some people who will resist the change. At this point, directing the change time period, supporting the workers' thoughts, ensuring the participation of the workers, informing them, and many other methods should be taken into consideration.

Advice resulted from this study, in which the healthcare workers' attitude towards the organizational change, can be listed as follows:

1. Before the change and during the change period, workers should be kept informed.

2. In the period of directing the change, leaders should be in charge.

3. Before the change, enough sub-structures should be prepared.

4. During the change period, teamwork should be provided.

5. When targets are reached, workers should be awarded. 


\section{References}

Batchelder, J. S., \& Ross, C. A. (2009). Effects of personnel policy on the public administration paradigm shift: From merit to neo-managerial. Journal of Social Science, 21(2), 153-159.

Dağ, S. (2010). Hemşirelerin değişim yönetimi ile ilgili görüşlerinin belirlenmesi [Determination of opinion on the change management nurses] (Post Degree Thesis, Haliç University, Healthcare Sciences Institute, Istanbul, Turkey).

DiMaggio, P. J., \& Powell, W. W. (1991). Iron cage revisited: Institutional isomorphism and collective rationality in organizational fields. The new institutionalism in organizational analysis. Chicago: University of Chicago Press.

Doyle, M. (1995). Organizational transformation and renewal: A case for reframing management development. Personnel Review, 24(6), 6-18.

Gizir, S. (2008). Örgütsel değişim sürecinde örgüt kültürü ve örgütsel değişme [Organizational culture and organizational change in the organizational change process]. Mersin University Educational Sciences Faculty Magazine, 4(2), 182-196.

Guevara, E. B., \& Mendidas, E. P. (2002). A comparative analysis of the changes in nursing practice related to health sector reform in five countries of The Americas. Pan American Journal of Public Health, 12(5), 347-353.

Gül, İ. (2014). Hastane çalışanlarının örgütsel değişime bakış açılarının incelenmesi: Afyonkarahisar ili örneği [Examination of organizational change perspectives of hospital staff: Afyonkarahisar example] (Post Degree Thesis, Süleyman Demirel University, Social Sciences Institute, Healthcare Management Department, Isparta, Turkey).

Gümüşel, B. (2006, August). Türkiye'de sağlık reformu: Sağlıkta dönüşüm projesi [Health care reform in Turkey: Health Transformation project]. Paper presented at Hyatt Regency Hotel Seminar Presentations, Turkey.

Hernandez, J. S., Dale, J. C., Bennet, K. E., \& Varkey, P. (2010). Challenges and opportunities for medical directors in pathology and laboratory medicine standardization, integration, and innovation. American Journal of Clinical Pathology, 133(1), 8-13.

Homedes, N., \& Ugalde, A. (2005). Human resources: The Cinderella of health sector reform in Latin America. Human Resources for Health, 3(1), 34-60.

Kabakcı, H. (2008). Ĕgitimde yenileşme çalışmaları ve öğretmenlerin ilçe Milli Ĕ̈itim Müdürlügü çalışmalarındaki yenileşme ve yeterliliklerine yönelik algı ve beklentileri [Education reform work and teachers' perceptions and expectations of the district directorate of national education for innovation and competence in work] (Post Degree Thesis, Yeditepe University, Social Sciences Institute, Istanbul, Turkey).

Karasar, N. (2002). Bilimsel araştırma yöntemi [Scientific research method] (12th ed.). Ankara, Turkey: Nobel.

Karasar, N. (2009). Bilimsel araştırma yöntemi [Scientific research method] (20th ed.). Ankara, Turkey: Nobel.

Kurşunoğlu, A., \& Tanrı̈ğgen, A. (2006). İlkögretim okulu öğretmenlerinin örgütsel değişmeye ilişkin tutumları [Attitudes toward organizational change of primary school teachers] (Post Degree Thesis, Pamukkale University, Social Sciences Institute, Denizli, Turkey).

Maynard, A. (2005). Competition in health care: what does it mean for nurse managers. Journal of Nursing Management, 13(5), 403-410.

Özyılmaz, Ö. (2013). Türk Milli Eğitim sorunları ve çözüm arayışları [Turkish National Education issues and the search for solutions] (4th ed.). Ankara, Turkey: Pegem Academy. 
Pollock, A. M. (2005). The privatization of our health care (4th ed.). London, UK: Verso.

Sargutan, E. (2005). Sağlık sektörü ve sağlık sistemlerinin yapısı [The structure of the health sector and health system]. Hacettepe Healthcare Management, 8(3), 15-19.

Sayan, İ., \& Küçük, A. (2012). Türkiye'de kamu personeli istihdamında dönüşüm: Sağlık Bakanlığı örneği. [The conversion of civil servants employed in Turkey: Ministry of Health sample]. Ankara University Journal of Faculty of Social Sciences, 67(1), 171-203.

Seren, A. K. (2014). Sağlık çalışanlarının sağlıkta dönüşüm projesine ilişkin görüşleri [Views on the transformation of health workers in health projects]. Healthcare and Nurse Management, 1(1), 19-21.

Uslu, D. (2006). Örgütlerde değişim ve değişim sürecinin işgörenlerce algllanması üzerine bir alan araştırması Să̆lık Bakanlığı Ankara Ĕ̆itim ve Araştırma Hastanesi Örneği [A field survey on the perception of change and change processes in organizations work coopted by the Ministry of Health Ankara Training and Research Hospital Case] (Post Degree Thesis, Gazi University, Educational Sciences Institute Department, Ankara, Turkey).

Yousef, D. A. (2000). Organizational commitment: A mediator of the relationships of leadership behavior with job satisfaction and performance in a non-western country. Journal of Managerial Psychology, 15(1), 6-24. 